\title{
Necrotic bark of common pine (Pinus sylvestris L.) as a bioindicator of environmental quality
}

\author{
Anna Chrzan
}

Received: 13 May 2014 / Accepted: 17 July 2014 /Published online: 10 August 2014

(C) The Author(s) 2014. This article is published with open access at Springerlink.com

\begin{abstract}
The aim of this study was to determine the $\mathrm{pH}$ and the concentration of lead, cadmium, nickel, copper and zinc in aqueous extracts of necrotic bark Pinus sylvestris L. and in adjacent soil, located in two types of forest habitat in different parts in the Niepołomice Forest in southern Poland. The Niepołomice Forest is located about $35 \mathrm{~km}$ east of an urbanindustrial agglomeration Kraków. Despite the lack of significant differences in pine bark reaction studied, there was a clear difference in contamination of both bark and soil with heavy metals. There was a correlation between the distribution of pollutants in the forest, and the direction of the prevailing winds. More heavy metals were accumulated in the pine bark and soil from the west than the east. The high content of lead, zinc, cadmium and copper in the soils most likely results from the inflow of gas and dust pollutants from the urban-industrial agglomeration of Kraków.
\end{abstract}

Keyword Heavy metals $\cdot$ Necrotic pine bark $\cdot \mathrm{pH}$ reaction . Niepołomice Forest

\section{Introduction}

Biosphere pollution imposes a need to search for bioindicators enabling evaluation of the quality of environment and identification of trends in its changes. Using biological materials in the determination of environmental pollution as indicators is a cheap and reliable method (Faggi et al. 2011). Various types of plant, lichens, mosses, bark and leaves of higher plants have

Responsible editor: Philippe Garrigues

A. Chrzan $(\bowtie)$

Department of Ecology, Wildlife Research and Ecotourism, Institute of Biology, Pedagogical University of Krakow, ul. Podbrzezie 3, 31-084 Krakow, Poland

e-mail: annachrzn871@gmail.com been used to detect the deposition, accumulation and distribution of metal pollution (Grodzińska 1982; Sawidis et al. 2011; Serbula et al. 2013). Tree bark is a sensitive indicator of environmental pollution, particularly of acidifying compounds and heavy metals (Al-Asheh and Duvnjak 1997). These contaminants affect the physicochemical properties of bark (Świeboda and Kalemba 1979; Santamaria and Martin 1997). The pH depends on the species, age and the health of the trees and on the soil they grow on (Medwecka-Kornaś et al. 1989; Szczepanowicz and Gawroński 2000). Among the studied barks of pine tree are Turkish red pine Pinus brutia Ten. (Baslar et al. 2009), Italian stone pine Pinus pinea L. (Oliva and Mingorance 2006), Austrian pine Pinus nigra Arnold. (Coskun 2006), Masson pine Pinus massoniana Lamb. (Kuang et al. 2007) and Scots pine (Pinus sylvestris L.) (Świeboda and Kalemba 1979; Huhn et al. 1995; Lippo et al. 1995; Poikolainen 1997; Schulz et al. 1999; Pöykiö et al. 2005; Saarela et al. 2005; Samecka-Cymerman et al. 2006). In Poland, atmospheric pollution may be well detected with the bark of common pine (P. sylvestris L.), being a sensitive and common (over $70 \%$ of all Polish trees) bioindicator, located at fixed sites, constantly influenced by the surrounding environment and easily sampled and analysed (Grodzińska 1978, 1982; Marko-Worłowska et al. 2011; Chrzan and MarkoWorłowska 2012). Examination of water extracts from tree bark provides data on its $\mathrm{pH}$ reaction (lowered by $\mathrm{SO}_{2}$ and $\mathrm{NO}_{x}$ in the air), electrolytic conductivity, ability to absorb chosen chemical elements and concentration of sulphates in extract (Schulz et al. 1999).

Soil also belongs among the components of the natural environment more sensitive to the effects of pollution, including $\mathrm{pH}$ changes caused by human activity (Kowalkowski 2002; Hernandez et al. 2003). Acidity is one of the key factors determining the course of many soil processes, affecting the functioning and efficiency of entire geoecosystems. Basically, it affects the living conditions of soil organisms, the 
availability of macro- and micronutrients necessary for plant growth and the processes of nitrification and the presence of toxic heavy metals (Gambuś and Gorlach 2001; GrucaKrólikowska and Wacławek 2006).

The study aimed to determine the $\mathrm{pH}$ reaction and concentration of lead, cadmium, nickel, copper and zinc in water extracts from necrotic bark of P. sylvestris $L$. and in soil surrounding the analysed trees, situated in two forest habitat types of the western and southern part of the Niepolomice Forest located in southern Poland, as well as to evaluate the environmental pollution in this area on the basis of abovementioned parameters.

\section{Materials and methods}

The study area covered the Niepołomice Forest, located ca. $35 \mathrm{~km}$ from Kraków and since many years considered as its "green lungs". The area extends at ca. 10,758 ha, includes ca. $80 \%$ of forest surface in the Niepołomice Forest District and includes several parts, presently separated, however once integrated.

Species composition in stands of the Niepołomice Forest is dominated by pine, attaining a frequency of $62 \%$. Bark was sampled from even-aged specimens of common pine growing in two sectors of the Niepołomice Forest, namely the fresh mixed broadleaved forest (in the western part of the southern complex of the Niepołomice Forest, in the Sitowiec Forestry), and the moist mixed broadleaved forest (in the ecotone zone of the southern part of the Niepolomice Forest, in the Baczków Forest District, near a highway, built at that time) (Fig. 1). The areas were covered by soils of similar type, namely brown acidic soils and podzols. All the samples were collected in the autumn in October.

Both sectors included trees of similar size (diameter at breast height of ca. $40-45 \mathrm{~cm}$ ) and age (ca. 45 years) and spaced at ca. 3-5 $\mathrm{m}$ from each other. For each tree, three samples of necrotic bark were collected, using a sharp knife, from all four sides of the trunk (southern, northern, western and eastern), at ca. $1.5 \mathrm{~m}$ from the ground. Surfaces covered with lichens or resin was avoided. Sampling was performed after a no-rainfall period, as recommended by other authors using the "bark test" (Medwecka-Kornaś et al. 1989). Additionally, topsoil samples, each of ca. $10 \mathrm{dag}$, were collected with a soil samples from the surrounding of examined trees, from the depth of ca. $5 \mathrm{~cm}$. In total, 96 samples of pine necrotic bark (P. sylvestris L.) and 24 soil samples were taken.

The obtained bark was dried in open air at ca. $25^{\circ} \mathrm{C}$, for ca. 30 days, and ground to powder in an electric grinder. Samples were prepared by mixing ca. $1 \mathrm{~g}$ of the powdered bark with $8 \mathrm{ml}$ of distilled water, at room temperature, and after $24 \mathrm{~h}$ were subjected to $\mathrm{pH}$ measurements using a WTW $330 \mathrm{pH}$ meter. Similarly, all soil samples were dried and used to prepare solutions, including $10 \mathrm{~g}$ of soil and $25 \mathrm{ml}$ of distilled water, in which $\mathrm{pH}$ was measured after $24 \mathrm{~h}$ from pouring water on to the soil. The next step of analytical studies involved preparation of soil and bark for mineralization. From each sample, $0.5 \mathrm{~g}$ of bark or ca. $1 \mathrm{~g}$ of soil was weighted out into a vial, afterwards filled with $4 \mathrm{ml}$ of $65 \%$ nitric acid. After mineralization $\left(2-3 \mathrm{~h}\right.$ at $\left.110^{\circ} \mathrm{C}\right)$ solutions were poured to volumetric flasks and filled with distilled water to $10 \mathrm{ml}$. Content of heavy metals (lead, cadmium, copper and zinc) in the mineralized soil and bark samples was determined in the AAS atomic absorption spectrophotometer (Cole-Parmer, BUCK 200A).
Fig. 1 Place of research in the Niepołomice Forest

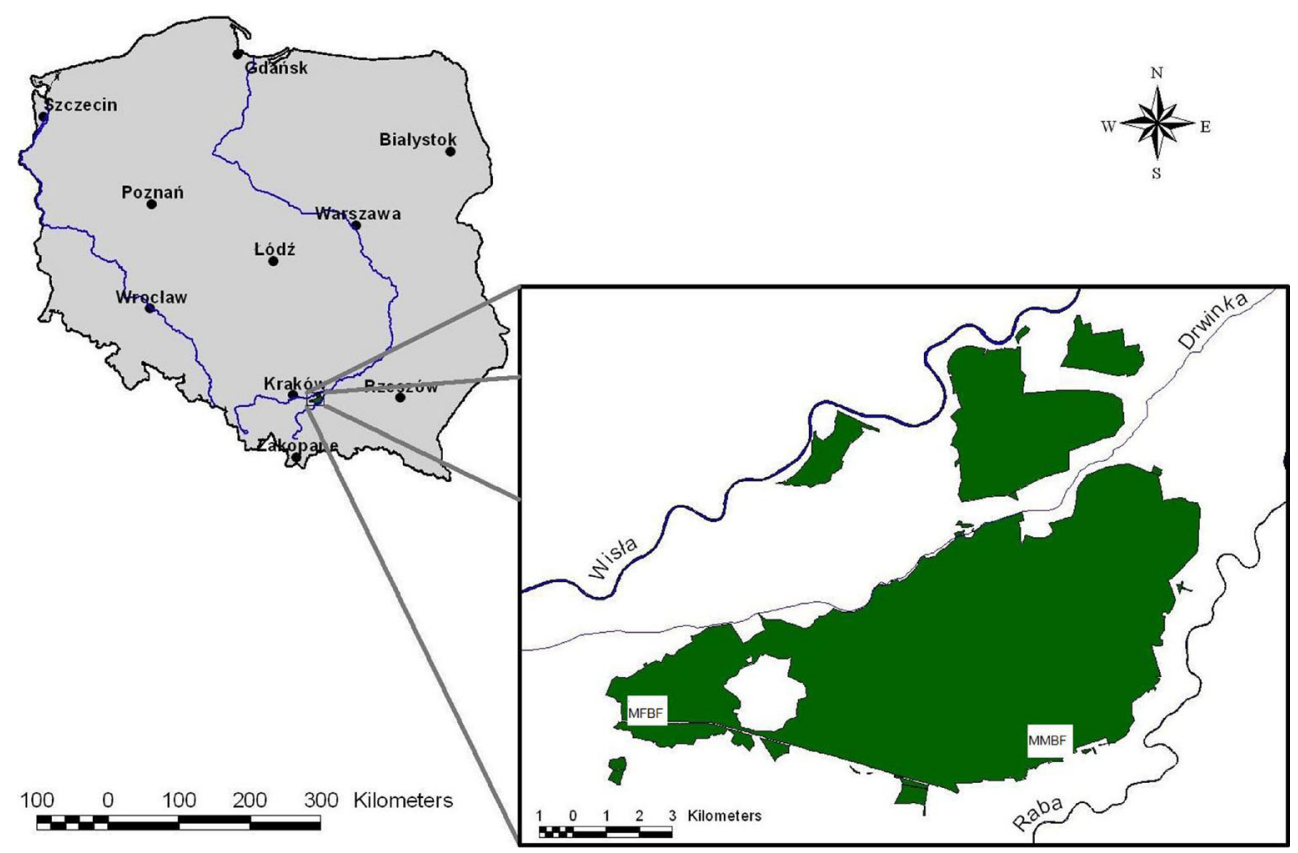


All the analyses were performed using STATISTICA 10 computer program. Results were subjected to analysis of variance with repeated measurements and Tukey's test. Relationships between the $\mathrm{pH}$ reaction in bark and soil and metal content in bark and soil were assessed with the Pearson linear correlation coefficient. The $p$ value assumed as statistically significant was $p<0.05$ and statistically highly significant was $p<0.01$.

\section{Results and discussion}

The $\mathrm{pH}$ of pine bark P. sylvestris L. indicated its much higher acidity than that of the soil in which these pine trees grew. The $\mathrm{pH}$ of the analysed pine bark ranged from $\mathrm{pH} 2.92$ to $\mathrm{pH} 3.25$ (Table 1). Similar acidity of pine bark (2.97-3.16) showed Bąbelewska (2013) in forest reserves, "Zielona Góra" and "Sokole Góry" near Częstochowa in Poland. Santamaria and Martin (1997) also recorded similar bark acidity for P. sylvestris L (3.17) in Navarra, Spain. A little lower $\mathrm{pH}$ values of the pine bark obtained in a study in the Niepołomice Forest by Grodzińska $(1978,1982)$. The Niepołomice Forest, located just a few kilometers from the large agglomeration of Krakow and a steel mill, reported acidification of pine bark in the range 2.2-3.0 (Grodzińska 1982). Grodzińska (1978) reported similar values of $\mathrm{pH}$ reactions in pine barks of Kraków and polluted areas of southern Sweden.

The low $\mathrm{pH}$ of pine bark was also reported in Ojcowski National Park (2.6-3.5) (Medwecka-Kornaś et al. 1989), the most polluted national park in Poland.

Lowering the $\mathrm{pH}$ of pine bark below 3.0 is dangerous and can result in changes in the health of the forest ecosystem. $\mathrm{pH}$ of common pine bark lower than 3.0 may increase the accessibility of heavy metals to plant tissues and therefore threaten the healthiness of forest ecosystems (Bąbelewska 2013).

Differences between the $\mathrm{pH}$ reaction of bark collected from various sides of the examined pine trunks appeared to be highly significant $(F=31.49 ; p<0.0001)$, with the highest values recorded for the western and eastern side (mean $\mathrm{pH}$

Table 1 Comparison of pine bark and soil (descriptive statistics)

\begin{tabular}{llllllll}
\hline Parameters & X & SD & Min & Q25 & Me & Q75 & Max \\
\hline pH bark W & 3.10 & 0.05 & 3.02 & 3.06 & 3.08 & 3.12 & 3.21 \\
pH bark E & 3.13 & 0.08 & 2.99 & 3.06 & 3.12 & 3.19 & 3.25 \\
pH bark N & 2.92 & 0.17 & 2.66 & 2.83 & 2.87 & 3.05 & 3.25 \\
pH bark S & 2.76 & 0.09 & 2.63 & 2.70 & 2.74 & 2.79 & 2.97 \\
pH soil W & 4.66 & 0.68 & 4.11 & 4.20 & 4.38 & 4.98 & 6.35 \\
pH soil S & 4.14 & 0.17 & 3.89 & 4.01 & 4.10 & 4.27 & 4.45 \\
\hline
\end{tabular}

$X$ mean, $S D$ standard deviation, Min minimum, $Q 25$ lower quartile, $M e$ median, $Q 75$ upper quartile, Max maximum, $W$ West, $E$ East, $N$ North, $S$ South
3.1). These two groups did not differ statistically from each other $(p=0.9027)$, however showed significantly higher values than bark $\mathrm{pH}$ at the northern side (mean 2.92). The lowest bark $\mathrm{pH}$ was determined for the southern side (mean $2.76)$, statistically different from $\mathrm{pH}$ at $\mathrm{W}(p=0.0002), \mathrm{E}(p=$ $0.0002)$ and $\mathrm{N}(p=0.003)$.

Soil $\mathrm{pH}$ was generally higher, with values ranging between 3.9 and 6.35 and attaining a mean of ca. 4.5 (Table 1). The investigated forest habitat types showed only small differences in soil and bark $\mathrm{pH}$, being slightly higher in the fresh than in the moist forest (Fig. 2). However, no statistically significant relationship was established between bark and soil $\mathrm{pH}$ at any of examined sides ( $p=0.5174 ; p=0.7253$ ).

Concentration of metals in bark varied at particular sides of collection and was also different from soil. At the western side, necrotic bark of the examined trees displayed the highest heavy metal concentrations, with $\mathrm{Pb}$ accumulated at greatest values ( $42.35 \mathrm{mg} \mathrm{kg}^{-1} \mathrm{~d} . \mathrm{m}$.), followed by $\mathrm{Zn}\left(40.85 \mathrm{mg} \mathrm{kg}^{-1}\right.$ d.m.), $\mathrm{Cu}$ (25.63 $\mathrm{mg} \mathrm{kg}^{-1}$ d.m.) and $\mathrm{Cd}\left(2.08 \mathrm{mg} \mathrm{kg}^{-1}\right.$ d.m.). Such high metal accumulation in the west-side bark may result from the direction of air movement in the Niepołomice Forest, dominated by western winds, carrying dust from the industrial agglomeration of Kraków. In contrast, the lowest metal content was generally recorded for bark from the southern side of trees $\left(\mathrm{Zn}-12.92 \mathrm{mg} \mathrm{kg}^{-1}\right.$ d.m., $\mathrm{Pb}-9.63 \mathrm{mg} \mathrm{kg}^{-1}$ d.m., $\mathrm{Cu}-4.74 \mathrm{mg} \mathrm{kg}^{-1}$ d.m.).

In areas less intensively affected by anthropogenic activity, accumulation of $\mathrm{Zn}$ is lower than in industrial areas and roadsides (Baslar et al. 2009).

The minimum mean zinc value was determined as $8.4 \mathrm{mg} \mathrm{kg}^{-1}$ d.m. in control areas, and the maximum mean value was determined as $14.1 \mathrm{mg} \mathrm{kg}^{-1} \mathrm{~d} . \mathrm{m}$. in industrial areas and roadsides in Western Anatolian part of Turkey (Baslar et al. 2009). Higher concentrations of $\mathrm{Zn}$ (up to $189 \mathrm{mg} \mathrm{kg}^{-1}$ d.m.) showed by Schulz et al. (1999) in Rösa, a polluted area in Germany.

Cadmium concentration in bark was the lowest at the northern side $\left(0.62 \mathrm{mg} \mathrm{kg}^{-1}\right.$ d.m.), while at the southern side,

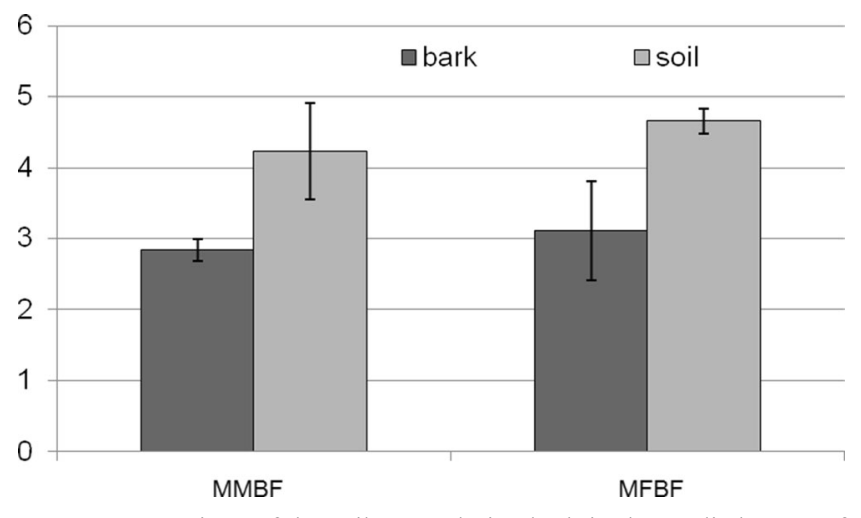

Fig. 2 Comparison of the soil $\mathrm{pH}$ and pine bark in the studied types of forest habitat $M M B F$ moist mixed broadleaved forest, $M F B F$ fresh mixed broadleaved forest 
it showed a significant $(p=0.0403)$ and negative $(r=-0.9456)$ correlation with Cd concentration in soil (Fig. 3). Schulz et al. (1999) showed in their work significantly lower mean of the metal - three times lower in Jostedalsbreen National Park in Norway, Syktyvkar in Russia and Neuglobsow in Germany, twice lower in Rösa, a polluted area in Germany, and only 1.5 times lower $\left(0.4 \mathrm{mg} \mathrm{kg}^{-1}\right.$ d.m.) in Białowieża, Poland.

Amounts of $\mathrm{Zn}, \mathrm{Cu}$ and $\mathrm{Pb}$ attained much higher values in soil than in bark (Figs. 3 and 4).

Compared to bark, mean $\mathrm{Zn}$ content in soil was over six times greater in the southern part of the forest and three times greater (119.33 mg kg-1 dry weight) in the western part (Fig. 3). However, correlations between soil and bark for $\mathrm{Zn}$ concentration were not statistically significant $(p>0.05)$. A significant positive correlation was observed for $\mathrm{Cu}$ content in soil at the western side and in bark at the eastern side ( $p=$ $0.0422, r=0.9404$ ).

Soils, specifically their humic horizon, are the main site of accumulation and strong fixation of anthropogenically derived lead. Soil $\mathrm{Pb}$ contamination is rather the result of many years of deposition enriched in transboundary leaded gasoline particles than of a local or regional industrial sources (Hernandez et al. 2003). The element, though of low mobility, in acidic and sandy grounds may become easily accessible to plants and consequently can be incorporated into food chains and impose a direct threat to organisms (Kabata-Pendias and Pendias 1999). In Poland, lead concentration in soil attains a mean value of $18 \mathrm{mg} \mathrm{kg}^{-1}$ and is most frequently recorded at amounts not exceeding $100 \mathrm{mg} \mathrm{kg}^{-1}$. Soil of the examined fresh mixed broadleaved forest included $52 \mathrm{mg} \mathrm{kg}^{-1} \mathrm{~Pb}$ (Table 2). However, $\mathrm{Pb}$ from airborne particles represents the present-day atmospheric conditions, whereas the soil surface reflects several years of atmospheric deposition.

This value was significantly and positively correlated with $\mathrm{Pb}$ content in bark ( $p=0.0449, r=0.9404)$. However, no correlation between concentration in soil and bark was established for other metals $(p>0.05)$.

The obtained results indicate increased content of copper, zinc, lead and cadmium in the investigated soils of the

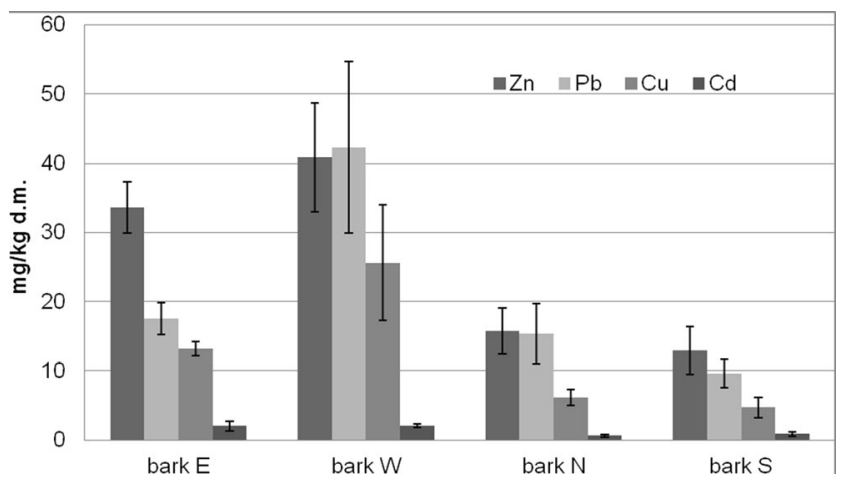

Fig. 3 Content of heavy metal in pine bark milligram per kilogram d.m. $W$ West, $E$ East, $N$ North, $S$ South

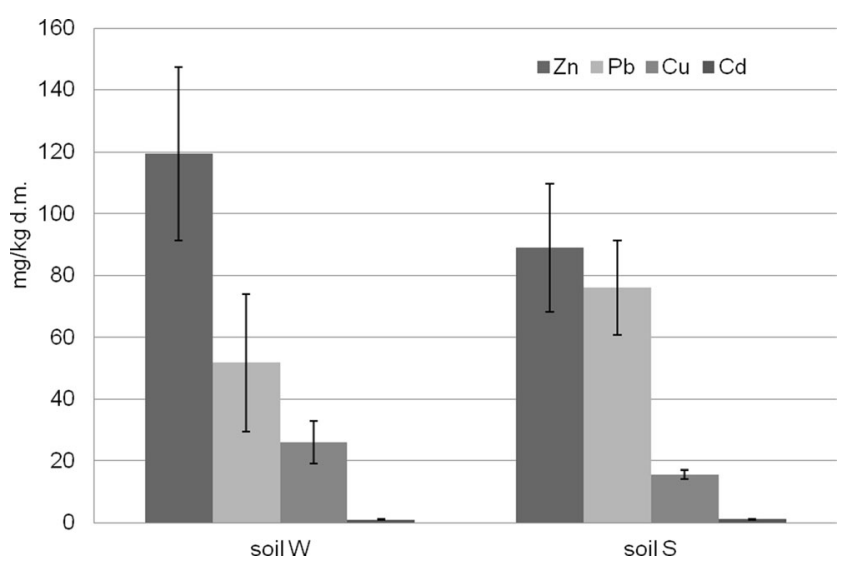

Fig. 4 Content of heavy metal in topsoil milligram per kilogram d.m. $W$ West, $S$ South

Niepołomice Forest. Much lower concentration of $\mathrm{Pb}$ (average $12.45 \mathrm{mg} \mathrm{kg}^{-1}$ d.m.), $\mathrm{Cu}\left(10.44 \mathrm{mg} \mathrm{kg}^{-1}\right.$ d.m.) and $\mathrm{Zn}$ (39.5 mg kg ${ }^{-1}$ d.m.) were showed in a natural reserve in Dinghushan in China (Kuang et al. 2007). The obtained results are in consent with studies by Hernandez et al. (2003), who concluded that high metal content in soils may be recorded both close to pollution sources and at greater distances, what results from the geographic location of sites and spreading of pollutants by winds, in the direction of their movement.

Enrichment of forest topsoil with heavy metals is likely to evidence their anthropogenic origin. Such a quality of soil environment results possibly from the inflow of gas and dust pollutants carried by western winds, mainly from the urbanindustrial agglomeration of Kraków. Consequently, soils of the western part of the Niepołomice Forest accumulated more zinc and copper, while soils of the southern part of the forest, adjacent to a highway, accumulated more cadmium and lead (Fig. 4).

Research of other authors (Härtel and Grill 1972; Poikolainen 1997; Harju et al. 2002; Kuang et al. 2007; Kakulu 2003; Sawidis et al. 2011; Guéguen et al. 2012) has confirmed that industrial activity tends to increase the concentration of metallic contaminants of barks. According to Huhn

Table 2 The average of heavy metal concentrations ( $\mathrm{mg} \mathrm{kg}^{-1} \mathrm{~d}$.m.) in soil and pine bark in Niepołomice Forest

\begin{tabular}{lllll}
\hline Metal & MMBF soil & MFBF soil & MMBF bark & MFBF bark \\
\hline $\mathrm{Zn}$ & $89.44(20.81)$ & $119.33(87.98)$ & $14.33(3.13)$ & $37.23(6.54)$ \\
$\mathrm{Cu}$ & $15.86(1.55)$ & $26.00(16.9)$ & $5.46(1.31)$ & $19.39(8.19)$ \\
$\mathrm{Cd}$ & $0.93(0.16)$ & $0.88(0.69)$ & $0.76(0.24)$ & $2.06(0.42)$ \\
$\mathrm{Pb}$ & $76.11(25.35)$ & $51.76(22.28)$ & $12.48(4.08)$ & $29.93(14.98)$
\end{tabular}

Numbers in the bracket are the standard deviations of the concentrations (SD)

$M M B F$ moist mixed broadleaved forest, $M F B F$ fresh mixed broadleaved forest 
et al. (1995) and Schulz et al. (1999), heavy metal concentrations of the barks were generally found to correlate very well with the heavy metals deposition.

The results of researches from Niepołomice indicate that concentrations of analysed heavy metals do not exceed boundary values defined in the Regulation of the Minister of Environment on soil quality standards and earth quality standards for group B soils, including the forest, tree-covered and shrub-covered soils, wastelands and built-up and urbanized areas, however excluding industrial areas, mining grounds and transport areas (Regulation 2002). Similar results were reported by other authors (Cieśla et al. 1994; SkwaryłoBednarz 2006).

\section{Conclusions}

Tree bark is a sensitive indicator of environmental pollution, particularly of heavy metals. The presented results confirm the usefulness of water extracts from bark of common pine (P. sylvestris L.) in research on the spatial variation and distribution of pollution in forests. Bark of trees examined in the western part of the Niepołomice Forest showed higher concentrations of $\mathrm{Pb}, \mathrm{Cd}, \mathrm{Zn}$ and $\mathrm{Cu}$ than in the southern part, most likely due to accumulation of pollutants inflowing from the urban-industrial agglomeration of Kraków with the dominant western winds.

Open Access This article is distributed under the terms of the Creative Commons Attribution License which permits any use, distribution, and reproduction in any medium, provided the original author(s) and the source are credited.

\section{References}

Al-Asheh S, Duvnjak Z (1997) Sorption of cadmium and other heavy metals by pine bark. J Hazard Mater 56(1-2):35-51

Bąbelewska A (2013) The impact of sulphur dioxide from Częstochowa Agglomeration on acidity degree of Pinus sylvestris L. bark of „Zielona Góra” and „Sokole Góry” Nature Reserves (Wyżyna Krakowsko-Częstochowska). Natural Environment Monitoring 14: 69-77

Baslar S, Dogan Y, Durkan N, Bag H (2009) Biomonitoring of zinc and manganese in bark of Turkish red pine of western Anatolia. J Environ Biol 30(5):831-834

Chrzan A, Marko-Worłowska M (2012) Content of heavy metals in soil and in pine bark in Skalki Twardowskiego Landscape Park in Krakow. Ecol Chem Eng A 19(10):1255-1262

Cieśla W, Dąbkowska-Naskręt H, Borowska K, Malczyk P, Długosz J, Jaworska H, Kędzia W, Zalewski W (1994) Trace elements in soils of selected areas Pomorza and Kujaw. Zesz Probl Postep Nauk Rol 414:63-70 (in Polish)

Coskun M (2006) Toxic metals in the Austrian pine (Pinus nigra) bark in the Thrace region, Turkey. Environ Monit Assess 121(1-3): 173-179
Faggi AM, Fujiwara F, Anido C, Perelman PE (2011) Use of tree bark for comparing environmental pollution in different sites from Buenos Aires and Montevideo. Environ Monit Assess 178(1-4):237-245

Gambuś F, Gorlach E (2001) Origin and harmful heavy metals. Aura 6: 11-13 (in Polish)

Grodzińska K (1978) Acidity of tree bark as bioindicator of forest pollution in Southern Poland. Water Air Soil Pollut 7:3-7

Grodzińska K (1982) Monitoring of air pollutants by mosses and tree bark. In: Steubing L, Jager HJ (eds) Monitoring of air pollutants by plants: methods and problems. Proc Intern Workshop (1981). Junk, The Hague Boston London, 33-42

Gruca-Królikowska S, Wacławek W (2006) Metals in the environment. Part II. Effect of heavy metals on plants. Chem Didact Ecol Metrol 11(1-2):41-54

Guéguen F, Stille P, Lahd Geagea M, Boutin R (2012) Atmospheric pollution in an urban environment by tree bark biomonitoring Part I: trace element analysis. Chemosphere 6(10):1013-1019

Harju L, Saarela K-E, Rajander J, Lill J-O, Lindroos A, Heselius S-J (2002) Environmental monitoring of trace elements in bark of Scots pine by thick-target PIXE. Nucl Instrum Methods Phys Res B 189: $163-167$

Härtel O, Grill D (1972) Die Leitfahigkeit von Fichtenborken - Extrakten als empfindlicher Indikakor für Lufverunreinigungen. Eur J For Res 2(4):205-210

Hernandez L, Probst A, Probst JL, Ulrich E (2003) Heavy metal distribution in some French forest soils: evidence for atmospheric contamination. Sci Total Environ 312(1-3):195-219

Huhn G, Schulz H, Stark HJ, Tolle R, Schurmann G (1995) Evaluation of regional heavy metal deposition by multivariate analysis of element contents in pine tree barks. Water Air Soil Pollut 84: 367-383

Kabata-Pendias A, Pendias H (1999) Biogeochemistry of trace elements. Państwowe Wydawnictwo Naukowe, Warszawa. (in Polish)

Kakulu SE (2003) Trace metal concentration in roadside surface soil and tree barks: a measurement of local atmospheric pollution in Abuja, Nigeria. Environ Monit Assess 89:233-242

Kowalkowski A (2002) Ecochemical indicators of forest soil condition damaged by acidification. Natural Environment 3:31-43 (in Polish)

Kuang YW, Zhou GY, Wen DZ, Liu SZ (2007) Heavy metals in bark of Pinus massoniana (Lamb.) as an indicator of atmospheric deposition near a smeltery at Qujiang, China. Environ Sci Pollut Res 14(4): $270-275$

Lippo H, Poikolainen J, Kubin E (1995) The use of moss, lichen and pine bark in the nationwide monitoring of atmospheric heavy metal deposition in Finland. Water Air Soil Pollut 85(4):2241-2246

Marko-Worłowska M, Chrzan A, Łaciak T (2011) Scots pine bark, topsoil and pedofauna as indicators of transport pollutions in terrestrial ecosystems. J Environ Sci Health Part A 46(2):138-148

Medwecka-Kornaś A, Kozłowska H, Gawroński S, Matysiak E (1989) The properties of extracts of the pine bark (Pinus sylvestris L.) as a pollution indicator in the Ojcowski National Park. Fragm Florist Geobot Polon 34(3-4):425-444

Oliva SR, Mingorance MD (2006) Assessment of airborne heavy metal pollution by aboveground plant parts. Chemosphere 65:177-182

Poikolainen J (1997) Sulphur and heavy metal concentrations in Scots pine bark in northern Finland and the Kola Peninsula. Water Air Soil Pollut 93(1-4):395-408

Pöykiö R, Perämäki P, Niemelä M (2005) The use of Scots pine (Pinus sylvestris L.) bark as a bioindicator for environmental pollution monitoring along two industrial gradients in the Kemi-Tornio area, northern Finland. Int J Environ Anal Chem 85(2):127-139

Regulation of the Minister of the Environment (2002) on the standards of the soil quality and ground quality. (Polish Journal of Laws 2002 No.165, item 1359 of 4 October 2002), (in Polish) 
Saarela K-E, Harju L, Rajander J, Lill J-O, Heselius S-J, Lindroos A, Mattsson K (2005) Elemental analyses of pine bark and wood in an environmental study. Sci Total Environ 343:231-241

Samecka-Cymerman A, Kosior G, Kempers AJ (2006) Comparison of the moss Pleurozium schreberi with needles and bark of Pine sylvestris as biomonitors of pollution by industry in Stalowa Wola (southeast Poland). Ecotoxicol Environ Saf 65:108-117

Santamaria JM, Martin A (1997) Tree bark as a bioindicator of air pollution in Navarra, Spain. Water Air Soil Pollut 98(3-4):381-387

Sawidis T, Breuste J, Mitrovic M, Pavlovic P, Tsigaridas K (2011) Trees as bioindicator of heavy metal pollution in three European cities. Environ Pollut 159(12):3560-3570

Schulz H, Popp P, Huhn G, Stärk HJ, Schüürmann G (1999) Biomonitoring of airborne inorganic and organic pollutants by means of pine tree barks: temporal and spatial variations. Sci Total Environ 232:49-55

Serbula SM, Kalinovic TS, Ilic AA, Kalinovic JV, Steharnik MM (2013) Assessment of airborne heavy metal pollution using Pinus spp. and Tilia spp. Aerosol Air Qual Res 13:563-573

Skwaryło- Bednarz B (2006) Total contents of selected heavy metals in forest soils of Roztocze National Park. Acta Agrophys 8(3):727-733

Świeboda M, Kalemba A (1979) The bark of Scots pine (Pinus sylvestris L.) as a biological indicator of atmospheric air pollution. Acta Soc Bot Pol 48(4):539-549

Szczepanowicz B, Gawroński S (2000) Water extracts from pine bark as a biological indicator of atmospheric air pollution. Sylwan 144(2): $107-118$ 